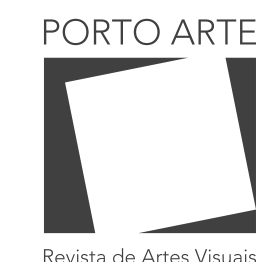

v. 25 n. 43

Jan/Jun 2020 e-ISSN: 2179-8001
Entendimentos e desacordos: das relações entre crítica, exposição e curadoria

Understandings and Disagreements: on the relationships between Criticism, Exhibition and Curatorship

\section{Francisco Dalcol}

ORCID: 0000-0001-8424-7139

Museu de Arte do Rio Grande do Sul (MARGS), Brasil.

\section{Resumo}

O artigo se desenvolve como uma investigação em torno das relações entre crítica, exposição e curadoria. Discutindo os deslocamentos dos modos e lugares de inserção e manifestação do discurso crítico, articula-se um campo de questões que denomino como os entendimentos e os desacordos que permeiam o debate sobre as relações entre crítica de arte e curadoria de exposição. A fundamentação metodológica e conceitual se assenta ao mobilizar referenciais quanto a debates críticos, antecedentes históricos e aportes teóricos, compondo o corpus a partir do qual questões são formuladas e a análise se encaminha. O interesse é refletir sobre no que se assemelham e diferenciam os papéis e funções do crítico e do curador, observando que vêm passando por transformações, contaminações e sobreposições cujas origens e consequências importa esclarecer e discutir. 0 artigo se vincula à pesquisa de tese de doutorado sobre a implicação da crítica de arte na formação do campo da curadoria contemporânea.

Palavras-chave

\section{Abstract}

Crítica de arte. Exposição. Curadoria. Teoria. Discurso.

This paper entails an investigation about relationships between criticism, exhibition and curatorship. Discussing the displacement of circulation and manifestation of critical discourse, the text articulates a field of questions that I call understandings and disagreements, and permeate the debate about the relations between art criticism and exhibition curation. The methodological and conceptual grounding is based on mobilizing references regarding critical debates, historical background and theoretical contributions, composing the corpus from which questions are formulated and the analysis is developed. It aims to reflect how the roles and functions of the critic and the curator resemble and differentiate from each other, observing that they have been going through transformations, contaminations and overlappings whose origins and consequences are important to clarify and discuss. The paper is linked to a doctoral thesis research on the implication of art criticism in the formation of the contemporary curatorship field.

Keywords

Art Criticism. Exhibition. Curatorship. Theory. Discourse. 


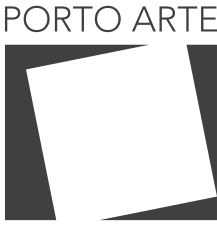

Revista de Artes Visuais

v. 25 ก. 43

Jan/Jun 2020 e-ISSN: 2179-8001

\section{1 - Dois críticos, duas visões sobre curadoria}

Em outubro de 2001, a propósito da mostra "Do corpo à terra - Um marco radical na arte brasileira", Frederico Morais publica no catálogo da exposição um texto em que avalia o significado da manifestação que organizara em $1970^{1}$, valendo-se do distanciamento factual e histórico que a circunstância lhe oferecia ${ }^{2}$. Ao apontar o que considera serem os aspectos inovadores dos eventos ocorridos então há três décadas, o crítico mineiro desenvolve uma reflexão em que enumera quatro itens, todos indicadores de práticas e concepções que contribuem significativamente para se compreender algumas das passagens operadas pelas linguagens artísticas contemporâneas naquele período no Brasil. Nas palavras de Frederico Morais:

1 - Pela primeira vez, no Brasil, artistas eram convidados não para expor obras já concluídas, mas para criar seus trabalhos diretamente no local e, para tanto, receberam passagem e hospedagem e, juntamente com os artistas mineiros, uma ajuda de custo; 2 - Se no Palácio houve um vernissage com hora marcada, no Parque os trabalhos se desenvolveram em locais e horários diferentes, o que significa dizer que ninguém, inclusive os artistas e o curador, presenciou a totalidade das manifestações individuais; 3 - Os trabalhos realizados no Parque permaneceram lá até sua destruição, acentuando o caráter efêmero das propostas; 4 - A divulgação foi feita por meio de volantes, distribuídos nas ruas e avenidas de Belo Horizonte, bem como nos cinemas, teatros e estádios de futebol, tal como já ocorrera com Arte no aterro $^{3}$ (MORAIS, 2006, p. 196) ${ }^{4}$.

Na sequência do mesmo texto, cujo tom de testemunho constitui um relevante documento sobre este que é um caso exemplar para a História das Exposições e da Curadoria no Brasil, Frederico Morais conclui a argumentação refletindo sobre como

\footnotetext{
1- Coordenada por Frederico Morais e Mari'Stella Tristão, a Semana de Arte de Vanguarda consistiu em dois eventos simultâneos e integrados em Belo Horizonte (MG): a mostra "Objeto e participação", no Palácio das Artes, inaugurada em 17 de abril de 1970, e a manifestação "Do corpo à terra", que se desenvolveu no Parque Municipal, de 17 a 21 de abril. Da primeira, participaram Carlos Vergara, Dileny Campos, Franz Weissman, George Helt, Lee Jaff, Ione Saldanha, Manoel Serpa, Manfredo de Souzanetto, Orlando Castaño, Yvone Etrusco, Teresinha Soares e Umberto Costa Barros. Da segunda, Alfredo José Fontes, Artur Barrio, Cildo Meireles, Décio Noviello, Dilton Luiz de Araujo, Eduardo Ângelo, Hélio Oiticica, José Ronaldo Lima, Lee Jaffe, Lotus Lobo, Luciano Gusmão, Luiz Alphonsus e Thereza Simões.

2- Em outubro de 2001, em comemoração aos 30 anos, foi realizada a exposição "Do corpo à terra - Um marco radical na arte brasileira", com curadoria de Frederico Morais. A mostra apresentou registros visuais e sonoros das obras e situações propostas pelos artistas nos eventos ocorridos em 1970, além de obras reconstruídas, dada a efemeridade de muitas das propostas e realizações. A mostra teve lugar no Itaú Cultural Belo Horizonte de 26 outubro de 2001 a 25 janeiro de 2002.

3- "Arte no aterro: um mês de arte pública" foi um evento coletivo e ao ar livre concebido e organizado por Frederico Morais com o apoio do jornal Diário de Notícias, entre 6 e 28 de julho de 1968. 0 evento abrangeu um conjunto de apresentações e manifestações de arte de vanguarda, além de aulas e atividades criativas para crianças e adultos.

4- Originalmente publicado em: "Do corpo à terra: um marco radical na arte brasileira". Belo Horizonte, Itaú Cultural, out. 2001 (catálogo de exposição).
} 


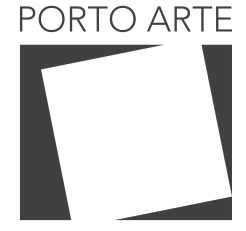

Revista de Artes Visuais

entende o seu papel à época, quando conciliou atividades como o exercício da crítica de arte em jornal e a atuação como agitador e organizador de ações públicas, eventos participativos e proposições coletivas.

\begin{abstract}
Finalmente, também, pela primeira vez, um crítico de arte atuava simultaneamente como curador e artista. Desde a realização da mostra "Vanguarda brasileira", eu já vinha questionando o caráter exclusivamente judicativo da crítica de arte, dando-Ihe uma dimensão criadora. A curadoria como extensão da atividade crítica, o crítico como artista (MORAIS, 2006, p. 196, grifo meu).
\end{abstract}

No que toca aos propósitos do presente artigo - e minimizando o autoalegado pioneirismo de Frederico Morais -, a relevância da afirmação de se dá pelo fato de situar a sua atuação como crítico de arte também no campo da curadoria, apontando assim antecedentes e aportes históricos para se pensar sobre as relações entre crítica e curadoria em artes visuais, sobretudo no Brasil. A passagem é ainda significativa por fornecer uma noção de curadoria enquanto desdobramento da crítica de arte, acrescida pelo fato de que tal entendimento parte de um questionamento por parte do crítico a respeito de sua própria atividade, a de crítico de arte. Mais especificamente, por Frederico Morais problematizar o caráter judicativo apontando a dimensão criadora que a crítica pode encontrar, tendo como campo de extensão a curadoria e também a criação artística.

Faço agora um avanço em exatos 16 anos. Em outubro de 2017, na primeira edição do "Encontros com a arte contemporânea", Ronaldo Brito afirma que pensar sobre as relações entre crítica e curadoria leva necessariamente a se tratar de uma questão mais ampla, que remete ao conceito mesmo de arte contemporânea no contexto de uma sociedade comunicacional e de consumo. Na palestra intitulada "Questões de crítica e curadoria de arte", o crítico carioca argumenta que a problemática que envolve a figura do curador na atualidade - e, por extensão, a curadoria de exposições - parte do fato de operar como uma instância central junto à mediação, estabelecendo-se como uma espécie de "tradutor" entre arte e público. Uma mediação que se daria "conforme" e "em conformidade" às instituições e ao sistema.

Essa mediação não é neutra. Envolve não só uma conformação do público, mas uma própria conformação da arte. Na medida em que a arte vai sendo mais e mais objeto de um pensamento curatorial

\footnotetext{
5- Exposição organizada por Frederico Morais em Belo Horizonte, aberta em 25 de julho de 1966, no prédio da Reitoria da Universidade Federal de Minas Gerais (UFMG). Apesar do título abrangente, reuniu apenas artistas cariocas ou atuantes no Rio de Janeiro, como Ângelo Aquino, Antonio Dias, Carlos Vergara, Dileny Campos, Hélio Oiticica, Maria do Carmo Secco, Pedro Escosteguy e Rubens Gerchman.

6- Esta edição de estreia do Encontros com a Arte Contemporânea ocorreu no Museu Vale nos dias 25, 26 e 27 de outubro de 2017. O evento dá sequência aos Seminários Internacionais Museu Vale, realizados entre 2006 e 2013
} 


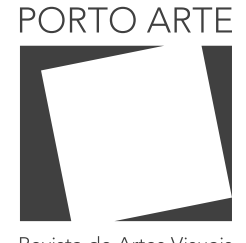

Revista de Artes Visuais que é estranho ao vir-a-ser dela como arte, que vai pedir a ela que fale a respeito das questões propostas em um nível quase sempre muito comunicacional, ela acaba transformada em matéria informativa pelo curador, que opera como um agente informacional.

Claro que estou simplificando e esquematizando, mas esse seria o horizonte problemático ao se transformar a arte em comunicação. 0 problema do curador e dessa prática curatorial é adequar a obra à forma dominante do mundo, que é informacional e comunicacional. Nesse sentido, o curador seria a antítese do crítico (BRITO, 2017, vídeo de palestra, grifo meu).

Como se pode notar, Ronaldo Brito encara com cautela as relações entre crítica e curadoria. Não chega a reprovar ou recusar as aproximações - na sequência de sua fala, chega a apontar a viabilidade de um pensamento crítico a partir do que denomina "curadoria poética". Em 2013, em uma entrevista-conversa com Marisa Flórido César na revista Arte \& Ensaios, Ronaldo Brito já falara a respeito dessas ideias, oferecendo outros elementos sobre seu posicionamento enquanto crítico que se dirige à curadoria. Em seu argumento, explicita os mesmos critérios que toma para si como crítico.

Só faço curadoria, quando faço, como uma extensão da crítica. Só curo exposições de artistas dos quais conheço o vir a ser da obra, o processo de linguagem, a poética. Minha crítica procura ser a propagação poética - por intermédio do veículo expressivo do verbo do conteúdo de verdade daquelas obras; a curadoria seria uma tentativa de espacialização poética. Não é o sentido dominante hoje (BRITO, 2013, p. 11, grifo meu).

Em sequência, Ronaldo Brito volta a abordar a posição do curador, argumentando que, mesmo quando independente, tende a atender à lógica das instituições e do sistema de arte. É relevante perceber que em sua fala está contida a ideia de uma passagem do crítico ao curador.
As obras devem encaixar-se num tema, num assunto, num discurso cultural, do qual o curador, em última instância, é o intérprete, o propositor. Os trabalhos já vêm discursados. Discursos que, em geral, representam contingências extrínsecas ao processo do trabalho e que determinam sua presença nesta ou naquela mostra. Enfim, o curador faz a leitura pública e propicia o aparecimento do artista no mundo.

Essa condição demonstraria o fim da autonomia moderna da obra 


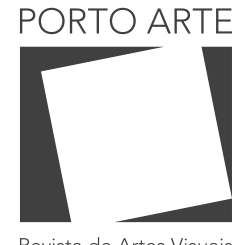

v. $25 n .43$ Jan/Jun 2020 e-ISSN: 2179-8001 de arte. A substituição de um olhar crítico, avaliativo e expressivo se dá por meio de uma manipulação cultural pública que dissemina sentidos muito mais relativos ao acontecimento da exposição, neste ou naquele lugar, do que sobre a lógica intrínseca do trabalho. Essa é a condição de realidade hoje, embora não seja absoluta. Não gostaria de colocá-la a partir das relações de poder; me cansa essa retórica batida. Mas, efetivamente, o curador tornou-se a instância dominante na relação pública com o trabalho (BRITO, 2013, p. 11, grifo meu).

Considerando as citações de Ronaldo Brito aqui convocadas, fica evidenciado que o seu alerta é à tendência de a curadoria e os curadores operarem não segundo a experiência que parta dos próprios trabalhos de arte e dos aspectos que os fundamentam, mas por tratamentos e abordagens que submetam as obras a um discurso estranho e extrínseco a elas, sujeitando a arte a corresponder a demandas endereçadas por um circuito artístico sobre o qual recaem os interesses de um sistema guiado pelas lógica do consumo e da mídia. Ao considerar essa questão, Ronaldo Brito coloca em suspeito a possibilidade de a tarefa e o exercício críticos se viabilizarem na posição em que o curador se encontra ao trabalhar a serviço de expectativas e finalidades previamente autorizadas e enquadradas pela circunstância institucional. Em outras palavras, pelo trabalho administrado do curador estar de antemão cooptado e subvencionado pelo próprio sistema que oferece as condições que viabilizam a sua atividade.

Relaciono Frederico Morais e Ronaldo Brito por considerar fecundo perscrutar e cotejar suas compreensões a fim de circunscrever a problemática em torno do tema de investigação que procuro colocar em causa neste artigo - a saber, as relações entre crítica, exposição e curadoria? (DALCOL, 2018). Primeiramente, porque são dois críticos reconhecidos por suas destacadas atuações e trajetórias refletindo sobre a curadoria a partir da crítica, sendo eles o que podemos considerar críticos stricto sensu, dadas as suas inserções públicas com a escrita em crítica de arte; mas são também dois críticos que se relacionam com a curadoria ao realizarem exposições, textos de apresentação, ensaios de catálogos de mostras e mesmo apreciações críticas relacionadas a mostras do circuito. Depois, porque se lançam à discussão sobre as relações entre os domínios da crítica e da curadoria apresentando pontos de vista que tocam em aspectos distintos, com argumentos que oferecem diferentes visões sobre um campo de questões que denomino como os entendimentos e os desacordos que permeiam a discussão sobre as relações entre crítica de arte e curadoria de exposição.

Se os posicionamentos de Frederico Morais e Ronaldo Brito sugerem divergências quanto ao entendimento da curadoria poder ser encarada enquanto extensão da crítica, acabam por convergir ao envolverem igualmente questões que se relacionam às transformações das últimas décadas verificadas nas práticas artísticas, assim como

7- Este foi o tema de investigação de minha tese de doutorado em Artes Visuais - História, Teoria e Crítica sob orientação da Prof. ${ }^{a}$ Dr. ${ }^{a}$ Ana Maria Albani de Carvalho (PPGAV/UFRGS). Cf: DALCOL (2018) 


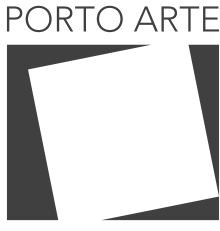

Revista de Artes Visuais

$\vee 25 n .43$

Jan/Jun 2020 e-ISSN: 2179-8001

nos modos de produção, circulação e exibição do trabalho de arte. Ao mesmo tempo, apontam para os deslocamentos do discurso crítico em direção a uma esfera ampliada da circunstância de apresentação da obra e do trabalho de arte.

São mudanças que, de um modo geral, relacionam-se às novas concepções e entendimentos sobre os processos e as estratégias de apresentação e recepção do trabalho de arte; aos borramentos de fronteiras e distinções entre os papéis e as posições do artista, do espectador, do crítico e do curador; e ao estabelecimento de um contexto em que o circuito artístico se torna fortemente institucionalizado e sobre cujos atores passam a incidir agenciamentos ainda mais intensificados pelo sistema.

\section{2 - Do crítico de arte ao curador de exposições}

Trata-se de um quadro amplo de profundas redefinições de categorias artísticas, estéticas e históricas, cujas injunções ultrapassam o meio artístico, englobando os campos da cultura, da economia e da política. Sem pretender estabelecer alguma relação de ordem ou de causa-e-efeito, entendo que essas alterações se relacionam a uma série de acontecimentos que atingem o campo da arte ao menos desde os anos 1960, tais como: a crise das vanguardas históricas e dos -ismos modernistas; o questionamento dos determinismos universalizantes, dos discursos evolutivos e das metanarrativas que embasavam e legitimavam determinada concepção de arte; os embates sobre o caráter judicativo e autoritário da crítica de arte; a inserção do artista e do próprio trabalho de arte na esfera da crítica - e da crítica na esfera da criação; o questionamento do museu e da instituição-arte em seus modos de exibir e imputar valor; a rarefação e o decréscimo de importância da crítica de arte na imprensa escrita; e a preponderância da atividade expositiva e curatorial no âmbito das instituições artísticas.

No que toca aos discursos sobre arte, em especial a crítica de arte, as consequências se fazem sentir nos seus modos e lugares de inserção pública. Nesse sentido, concordo com a pesquisadora Glória Ferreira (2010, p. 147), segundo quem presenciamos "diversos níveis de deslocamentos da atividade crítica". Identifico isso na medida em que observo que esses deslocamentos se dão em direção à circunstância de apresentação e recepção do trabalho de arte. Algo que envolve não só os domínios da produção artística, mas novas funções, agentes e instâncias relacionados à divisão e à especialização do trabalho, entre os quais o curador e as instituições artísticas concorrem a faces mais visíveis do processo.

Alterações como essas são também abordadas por Ahu Antmen em uma análise em que compara o desenvolvimento histórico do papel do crítico e do curador. No texto "The Critic's Role in The Age of The Curator", a crítica e historiadora da arte turca argumenta sobre as mudanças que verifica na esfera da mediação, apontando que o curador teria assumido o papel e a função que anteriormente cabiam ao crítico. Em suas palavras: "Há uma mudança significativa no controle da recepção e do consumo de exposições e obras de arte hoje, uma mudança definitiva das observações do crítico para as ideias do curador" (ANTMEN, 2006, p. 70). Argumento que leva Ahu Antmen à 


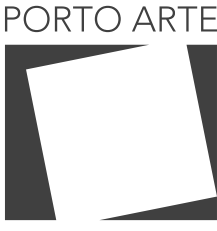

Revista de Artes Visuais

v. 25 ก. 43

Jan/Jun 2020 e-ISSN: 2179-8001

afirmação que motiva seu ensaio: "Sem dúvida, vivemos hoje na era do curador" (p. 66)․

À constatação da "era do curador" em Ahu Antmen, relaciona-se uma questão frequente nesse debate: o argumento de que o crítico teria cedido lugar ao curador, de que o curador seria o novo crítico, sendo um o substituto do outro. Percebo que tal assunção aparece já em debates nos anos 1970, ganhando maior destaque a partir dos anos 1980 na esteira do incremento de instituições artísticas e das grandes exposições de caráter temporário e também itinerante, bem como da paralela ascensão do curador como figura de prestígio e poder no circuito artístico internacional. Um texto exemplar a respeito dessa alegada substituição do crítico pelo curador é "O fardo da curadoria", de Olu Oguibe. Neste ensaio de 2002, o artista, professor, crítico e curador nigeriano reflete sobre as transformações que identifica àquela altura, lançando a seguinte sentença na abertura do texto:

Na segunda metade do século $X X$, surgiu uma nova figura, na posição de agente cultural influente, que acabaria por roubar de modo eficaz a posição suprema da crítica e do historiador da arte no discurso da arte contemporânea. A figura era a do curador, diretor ou comissário de exposições. Entre os anos de 70 e 90, à medida que os acadêmicos e críticos se tornam menos influentes nas decisões sobre o destino da carreira do artista - especialmente na cultura metropolitana -, o curador começou cada vez mais a definir a natureza e a direção do gosto na arte contemporânea - tanto assim que, na virada para o século XXI, o curador passa então a representar a figura mais temida e talvez a mais odiada da arte contemporânea (OGUIBE, 2004, p. 7, grifo meu).

Mesmo que a afirmação se aplique ao que possa ser verificado e constatado em diferentes meios artísticos, entendo que deva ser problematizado o caráter unívoco contido na alegação de que o curador de exposição passou a exercer um papel e a ocupar um lugar que pertenciam ao crítico e ao historiador da arte. Ou que os "roubou", para usar as palavras de Oguibe. Embora seja fato que o curador tenha sido elevado a posição de destaque - e também a deter maior autoridade, influência e poder de legitimação -, a meu ver o quadro de alterações das décadas recentes, que sumariamente elenquei nos parágrafos anteriores, não resulta simplesmente no fato de que o crítico de arte tenha sucumbido ao curador de exposição. Mas que suas funções e identidades vêm passando por transformações, contaminações e sobreposições, cujas origens e consequências importa esclarecer e discutir.

Nesse sentido, compartilho de outro entendimento de Glória Ferreira (2010, p. 147), reconhecendo, assim como ela, que "a atividade curatorial vem introduzindo no-

\footnotetext{
8- Pode ser válido mencionar que a discussão teve lugar no $40^{\circ}$ Congresso da AICA em Paris, em 2006, em uma sessão cujo título - "The Curator and the Critic: Parallel Training" - já indica as preocupações sobre os tensionamentos entre crítica e curadoria.
} 


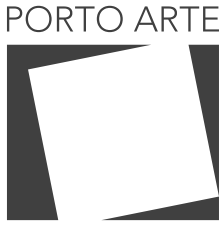

Revista de Artes Visuais

$\vee 25 n .43$

Jan/Jun 2020 e-ISSN: 2179-8001

vas modalidades de circulação da crítica, estabelecendo outros nexos entre os fatos artísticos e as descrições, avaliações e interpretações". Uma linha de pensamento que também encontro em um texto do pesquisador Ivair Reinaldim, intitulado "Tópicos sobre curadoria" (2015). Após apresentar uma série de pontos de vista sobre o entendimento de curadoria, o pesquisador assinala dois aspectos que se constituem a meu ver relevantes: uma verificável sobreposição entre as atividades da crítica e da curadoria, no que diz respeito a orientações e metodologias em comum; e a compreensão de que a curadoria descenderia da crítica, a partir dos deslocamentos de um meio a outro nos modos de manifestação pública.

[...] o que importa é a constatação da similaridade entre a condição outrora ocupada pelo crítico de arte - seja como quem emite juízo crítico (caricatamente, legitimando ou condenando obras e artistas), como mediador na construção de sentidos ou como parceiro, incentivador e colaborador de artistas - e a atividade exercida atualmente pelo curador, o que reforça uma relação simbiótica entre o que outrora se entendia como crítica de arte e o que atualmente compreende-se como curadoria. A prática curatorial atual, então, mais do que uma decorrência da conservação de acervos e da museologia, seria um desdobramento do exercício da crítica, passando de um veículo (sobretudo o jornal) para outros (exposição, catálogo, livro etc.) (REINALDIM, 2015, p. 18, grifo meu).

De fato, se considerarmos que originariamente o curador é o profissional e especialista responsável pelo estudo, guarda e conservação de coleções e pela organização de exposições no âmbito dos museus (HUGHES, 2008; OGUIBE, 2004), é necessário reconhecer que passou a exercer com maior intensidade a partir dos anos 1960 um papel crítico e de agente discursivo que colabora para a formulação de novas narrativas, intuições e experiências com arte (O'NEILL, 2012; OSORIO, 2015; SMITH, 2012). E que, além disso, em sua função vem operando como importante agente mediador por meio das exposições (GONÇALVES, 2004, 2005, 2008), circunstância de apresentação e recepção em que se dá em grande parte na contemporaneidade o contato entre arte e público, entre gesto criador e experiência instauradora (CARVALHO, 2005, 2012, 2014).

Ao mesmo tempo que é constatável o lugar de destaque adquirido pela curadoria nas últimas décadas, por outro lado o seu desenvolvimento desde os procedimentos museológicos até sua afirmação enquanto campo interdisciplinar de investigação em artes visuais tem oferecido importantes contribuições às práticas, metodologias e modelos tanto da crítica de arte como da história da arte. Talvez mais importante do que afirmar substituições ou prevalências seja compreender como as mudanças impactam na configuração dos territórios de cada disciplina. E como uma passa a se relacionar com a outra, muitas vezes cambiando e se inter-relacionando. 


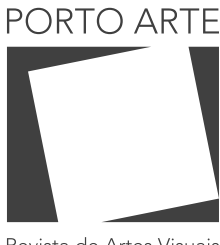

$\vee 25 n .43$ Jan/Jun 2020 e-ISSN: 2179-8001

\section{3 - A curadoria enquanto espaço de crítica}

É inegável que a prática e o pensamento em exposição e curadoria venham propondo novos modos de pensar e experienciar a arte, colaborando para a difusão de discursos críticos e formulando novos argumentos de ordem teórica, crítica e historiográfica. Ao modo como entendo, participando de um campo discursivo e ao mesmo tempo formulando espaços de crítica.

Algumas questões relevantes que colaboram para o aprofundamento desse argumento são levantadas por Lisbeth Rebollo Gonçalves no livro "Entre cenografias: o museu e a exposição de arte no século XX" (2004). Ao argumentar sobre o caráter crítico da curadoria e a figura do crítico-curador, lança afirmações como: "o curador concebe a exposição como um projeto crítico" (p. 41), "o curador impulsiona a revisão de significados e coloca-a em constante reconstrução, dentro do marco conjuntural de seu tempo" (p. 110), "o conceito de curadoria surge no cenário artístico brasileiro na década de 1980, afirmando-se a figura do curador como um agente mediador na década de 1990" (p. 110). Nesse mesmo estudo, Lisbeth Rebollo Gonçalves também propõe uma definição sobre o que seria a tarefa crítica do curador, ressaltando:

\section{[...] a importância da ação consciente do curador na sua tarefa crí- tica de aproximar ou separar significados, distinguir, descrever, expli- car e analisar, de modo a instigar o público receptor a ingressar no processo de discussão da ideia proposta pela exposição (GONÇAL- VES, 2004, p. 110, grifo meu).}

Se pensarmos detidamente, o argumento estabelece profundos paralelos entre o crítico e o curador. Os diversos verbos empregados em relação "à tarefa crítica do curador" - "aproximar, separar, distinguir, descrever, explicar e analisar" - não são nada estranhos à crítica de arte, em especial tendo em conta a sua etimologia. Lembremos que crítica vem dos termos gregos kritérion e kríno, que emprestam os significados de separar, discernir, escolher, julgar; sendo que krísis corresponde a decisão, e krités a juiz. Recordemos ainda que crítica tem também sua raiz no latim: vem de cerno, de discernir. Já em sentido moderno, como anota Maria José Justino (2005, p. 14), crítica "surge como uma atividade humana voltada para os julgamentos, em particular os julgamentos de apreciação (juízo de valor) da obra de arte". Vem daí, portanto, o caráter tanto de avaliação como de interpretação que a crítica assume - e também de autoridade e julgamento.

Isso posto, pode-se concordar com a aproximação que Lisbeth Rebollo Gonçalves sugere entre o crítico e o curador. Mas desde que se reconheça uma diferença significativa, por ela mesma colocada: "instigar o público receptor a ingressar no processo de discussão da ideia proposta pela exposição". Como fica claro, não se está falando somente do encontro entre um público leitor e um texto opinativo-avaliativo de um crítico, mas de um ator - o curador - cuja prerrogativa seria a de proporcionar uma mediação 


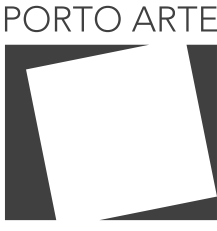

Revista de Artes Visuais

$\vee 25 n .43$

Jan/Jun 2020 e-ISSN: 2179-8001

com vistas ao público que vai ao encontro da experiência proporcionada pela exposição de que é responsável. Contudo, mesmo com a distinção, entendo que uma similaridade permanece: tanto crítico como curador se manifestam publicamente, sendo ao mesmo tempo sujeitos e objetos de debate e discussão.

O importante aqui é frisar o maior caráter público que tanto a função da curadoria como o sujeito curador passam a adquirir, ao deixar de se restringir ao responsável por um acervo ou por exposições no interior de um museu para designar também um agente criador e realizador de exposições que passa a exercer sua atividade com maior visibilidade e repercussão públicas.

Em outro texto, "Arte contemporânea e crítica de arte" (2005), Lisbeth Rebollo Gonçalves atribui tanto ao curador como ao crítico o papel de quem compreende as mudanças das linguagens artísticas contemporâneas, das formas de expor e da função das instituições. E manifesta em forma de pergunta sua visão favorável sobre o curador também se fazer crítico: "Até que ponto, mais do que nunca, o papel desse profissional seria o de um crítico de arte?" (GONÇALVES, 2005, p. 38). A sugestão dessa convergência ganha mais elementos na sequência do texto, quando afirma que o trabalho do crítico pode se dar tanto na prática ensaística do comentário quanto na organização de exposições:

O crítico colabora, sempre, para produzir a inserção das obras de arte na história. [...] Dessa forma, o crítico, como o curador, atua no processo de legitimação da arte contemporânea no seguinte sentido: identificando-a em relação a fontes históricas do passado distante ou próximo, de modo que, assim explicada, ela seja colocada, mesmo com seus efeitos de novidade, na teia da história. 0 crítico acelera a sua "historicização" e reorganiza o sistema artístico (GONÇALVES, 2005, p. 41, grifo meu).

A partir dessa discussão, a curadoria de exposição é encarada como atividade e tarefa crítica. E essa modalidade de crítica - que tende mais a discurso crítico interdisciplinar do que a crítica de arte nos termos tradicionais - encontraria na exposição um lugar de exercício e manifestação. Seja como for, importa aqui reter o sentido de que a exposição - ainda que cumprindo intenções e objetivos determinados - é entendida como lugar estratégico de comunicação, espaço público para conhecimento sobre arte, situação de ativação sensível e vivência estética. A meu ver, um potencial espaço de crítica.

Ao mesmo tempo que o papel mediador e o endereçamento público estabelecem paralelos quanto aos antecedentes das relações entre crítica, exposição e curadoria, parecem ter permanecido como uma característica em comum, o que nos remete aos processos de comunicação que a arte encontra na contemporaneidade. Tendo em conta algumas questões próximas, Mônica Zielinsky observa que desde cedo a exposição apresenta vínculos fortes e indissociáveis com a crítica de arte, no sentido de que am- 


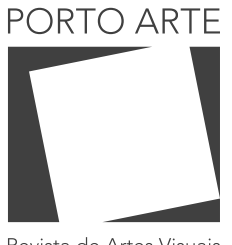

v $25 n .43$ Jan/Jun 2020 e-ISSN: 2179-8001

bas se inserem na esfera pública em caráter também de mediação.

A crítica de arte, desde seus primórdios, estabelecia os contatos entre a produção artística e a sua extensão pública. [...] Crítica de arte e mostras de arte são formas de estabelecer essas conexões e qualquer análise do produto artístico na cultura dos nossos tempos não pode mais prescindir dos estudos sob o ângulo de sua mediação (ZIELINSKY, 2006, p. 221, grifo meu).

Ao ter de elaborar seu esquema de sentido, o curador não deixará de ser remetido à atividade avaliativa e apreciativa do crítico e mesmo do historiador da arte, tendo necessariamente de expor algum ponto de vista em forma de conceito ou tema, determinar o mote da exposição por meio de seleções, agrupamentos e articulações. Ao curador será encomendado e mesmo exigido o texto em que se assenta a exposição, o ensaio em que desenvolve e fundamenta o argumento curatorial. Como assinala Ahu Antmen (2006), o curador hoje não é apenas um indivíduo criativo, mas também um indivíduo que precisa necessariamente ter opinião e agenda. Não só necessita ter um posicionamento, o seu partido, como instrumental teórico, preferencialmente interdisciplinar, e que não escapa à crítica, teoria e história da arte. Essa é uma opinião próxima à de Jacques Leenhardt (2000, p. 22), segundo quem os curadores são "os interventores imediatamente contemporâneos da criação, diretamente implicados na avaliação e interpretação das obras propostas pelos artistas".

Mas, ainda que o curador tenha especialidades e posicionamentos críticos, não há como negar o enquadramento institucional e as decorrentes demandas e exigências corporativas. A respeito dessas subordinações e contingências, retomo meu argumento, na indagação quanto a se a curadoria de exposição oferece um potencial espaço de crítica, ainda que distinto da tradicional forma estritamente escrita de manifestação da crítica. Agnaldo Farias (2013, p. 178) discute algo semelhante, ao assinalar que "o crítico também migrou para a prática curatorial" e ao ressaltar "que a prática curatorial revelou-se uma extensão possível e fértil para o crítico, diante de uma produção marcada pela variedade de disciplinas, e ainda mais colocada em confronto direto com a arquitetura e com o público". Para Francisco Alambert, esse movimento contribui também para a redefinição do papel do velho curador: "Não mais a tradicional figura do conservador da obra de arte ou de seu acervo, mas agora aquele que organiza a exposição dessa obra e desse acervo como quem faz um discurso, como quem cria sentido" (2014, s/nº).

Aqui, aproximamo-nos do já mencionado deslocamento dos modos e lugares de inserção e manifestação do discurso crítico, em direção a uma esfera ampliada da circunstância de apresentação da obra e do trabalho de arte. Também se relaciona à discussão sobre os desdobramentos desse campo expandido, sobretudo ao se reconhecer que a curadoria passou a assumir maior importância na medida em que as exposições em museus e instituições vieram a se tornar, mais e mais, locais e situações referenciais para o sistema da arte. É nesse mesmo sentido que importa apontar para 


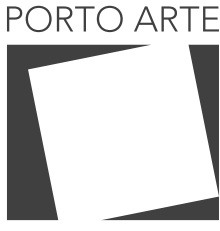

Revista de Artes Visuais

a necessidade de se perceber e discutir mais detidamente no que passam a se aproximar e afastar os papéis e funções do crítico e do curador. Luiz Camillo Osorio é uma das vozes a argumentar pertinentemente sobre a curadoria enquanto possibilidade de desdobramento da atividade crítica e, ao mesmo tempo, com chances de operar como uma instância crítica dentro do espaço institucional. Essa compreensão passa pela própria definição do que se pode entender por crítica.

O modo como enxergo a função da crítica tem muito a ver com o que penso ser importante na atividade curatorial. Vejo a crítica mais como um diálogo junto às obras do que um veredito sobre elas. Esta caracterização talvez retire da crítica uma pegada atritiva e polêmica, muitas vezes importante. Entretanto não se trata de uma escolha, mas de uma forma de ser convocado pela arte e pelo texto: forma essa que leva a um exercício reflexivo e hesitante (OSORIO, 2015, p. 66, grifo meu).

Nesse mesmo texto, intitulado "Virada curatorial: o pôr-em-obra da exposição como poética relacional", Osorio prossegue sua argumentação requalificando o estatuto da crítica ao modo como entende o exercício judicativo.

Sendo bem sucinto: fazer da crítica e da curadoria uma forma de "pensar junto" às obras e não sobre elas. Para muitos, este "pensar junto" da crítica retiraria dela a sua dimensão genuína de combate e de ajuizamento. Restariam condescendência e docilidade, impondo ao texto crítico (e consequentemente à curadoria em seguida) uma submissão acrítica ao mundo da arte - e mais perigosamente ainda ao mercado. Não nego que riscos existem, mas o ponto principal é requalificar a relação entre crítica e juízo e o estatuto do juízo no desdobramento de sentido da arte, no modo pelo qual as obras vão se legitimando historicamente e produzindo novas formas de sentir e novos dispositivos judicativos. o que quero enfatizar é que ajuizar não implica uma deliberação hierárquica, devendo ser visto como um "pôr em relação" que sublinha diferenças (OSORIO, 2015, p. 66, grifo meu).

Em lugar do caráter normativo herdado da crítica de tradição moderna, há aqui a defesa do caráter reflexivo demandado pela própria experiência proporcionada pela arte. Ou seja, não se trata de um entendimento prescritivo e exterior às obras, mas de apontar uma noção de efetividade do pensamento crítico junto à arte com chances de encontrar espaços de manifestação na prática da curadoria. 


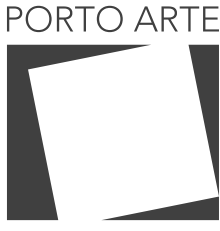

Revista de Artes Visuais v. 25 ก. 43 Jan/Jun 2020 e-ISSN: 2179-8001
Uma visão semelhante sobre essas questões é a de Ivair Reinaldim no texto já referenciado "Tópicos sobre curadoria", em que argumenta que a prática curatorial pode ser compreendida como desdobramento da crítica de arte, atividade historicamente exercida por pessoas de diferentes formações (literatura, filosofia, jornalismo, direito, artes visuais etc.).

Acrescentaria a essas transformações a consideração de que o crítico e mesmo o curador, enquanto figuras públicas, parecem se inscrever menos como "legisladores" do que "intérpretes", fazendo aqui referência à discussão proposta por Zygmunt Bauman (2010) a respeito do papel do intelectual na "pós-modernidade". Afinal, como sentencia Maria José Justino (2005, p. 32), "a crítica continua sendo fundamentalmente interpretação e reflexão".

Argumentando sobre "o declínio da autoridade carismática do crítico", Marisa Flórido Cesar (2015, p. 58) afirma que, "no lugar do legislador, daquele que determina a priori os destinos da arte, entra em cena, supostamente, o propositor de hipóteses infinitas de exposição". No texto intitulado "Curadoria: deslocamentos, impasses, possibilidades", a pesquisadora nos lembra que qualquer recorte curatorial é fruto de uma escolha e que, por isto, não exclui o seu caráter arbitrário. E que, em lugar de grandes verdades, o curador criaria "molduras de inscrição efêmera para a obra", lançando "pequenas hipóteses de aproximação e acesso", de modo a abrir "campos provisórios de significação". Nesse sentido, o curador passaria a ser visto como aquele que toma a obra e a inscreve em uma determinada situação expositiva.

Percebo aí algo da "identidade multifacetada" que caracterizaria a curadoria a que se refere Ahu Antmen (2006). Em seu argumento, essa identidade multifacetada se daria pelo curador ecoar tanto o crítico quanto o trabalho interdisciplinar que realiza: "Há algo de ambos, artista e crítico nessa identidade. Há invenção. Há produção. E há avaliação" (ANTMEN, 2006, p. 66)

Com relação ao crítico, Ahu Antmen lembra que seu papel tradicional sempre foi o 


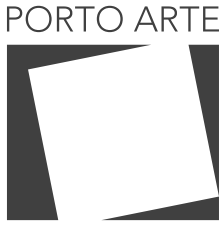

Revista de Artes Visuais v. 25 ก. 43 Jan/Jun 2020 e-ISSN: 2179-8001

de dar seu parecer sobre as exposições, a fim de abordar obras, artistas e eventos de dimensão e interesse do público, de modo a esclarecê-lo. Afirma ela: "Na época, eram as obras tornadas memoráveis pelos críticos - tanto em termos positivos ou negativos - que serviam para a realização da história da arte. Em suma, o público precisava de um mediador" (ANTMEN, 2006, pp. 69-70). Ao concluir seu argumento, Ahu Antmen sugere que hoje o mediador parece definitivamente ser o curador em vez do crítico.

\begin{abstract}
É o curador que aponta e analisa obras de interesse para esclarecer o público e servir na confecção da história da arte. 0 curador tem a chance de fazer isso não só verbalmente, mas visualmente. Em longo prazo, não é apenas fazer a história da arte, mas a realização de toda a cultura da prática da arte em si (ANTMEN, 2006, p. 70).
\end{abstract}

Contudo, Ahu Antmen reconhece que a curadoria se dá como uma posição interior, enquanto o crítico teria a chance de olhar de fora, tendo como prerrogativa, acima de tudo, tomar uma posição mais crítica na discussão de uma exposição e em todos os aspectos que a envolvem dentro do contexto da indústria cultural. Nesse sentido, é relevante observar a separação que a autora estabelece entre o que seriam os limites referentes aos papéis e funções do crítico e do curador, bem como os seus graus de isenção.

\footnotetext{
As ideias do curador podem ser muito críticas, a obra que ele/ela está mostrando pode ser muito crítica, mas um curador, mesmo independente, ainda funciona dentro do quadro geral de certas instituições. $E$ um curador, não importando a extensão de sua postura crítica, ainda é o "fazedor" de uma exposição, apresentando o seu trabalho sob a forma de uma "ideia visualizada", para ser consumida culturalmente e avaliada pelos espectadores e críticos. 0 curador avalia a cultura visual dos nossos tempos, a cena contemporânea e tendências da produção artística, e o legado de certas teorias na prática artística, mas creio ser aí que a avaliação do curador termina e deve terminar: o resto da avaliação - a avaliação do que foi apresentado ao público - certamente ainda deve ser o papel do crítico (ANTMEN, 2006, p. 70).
}

Essa sugerida separação entre os papeis e lugares do crítico e do curador remete à discussão que encontro em um texto de Delfim Sardo (2016, p. 81). Ao argumentar sobre a função de mediação e o caráter de disponibilização pública que marcariam os processos curatoriais, defende se tratar de uma prática crítica no sentido etimológico, pois "parte de uma crise que se abre entre o processo criativo e o estatuir dos espaços ficcionais e representacionais nos quais a arte é reconhecida enquanto tal". Para o crítico e curador português, a curadoria corresponderia assim à "construção de possibilidades de performar o artístico a partir de um acontecimento que performa também o 


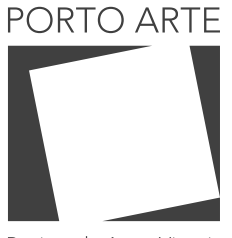

Revista de Artes Visuais v. 25 ก. 43 Jan/Jun 2020 e-ISSN: 2179-8001

espectador", sendo que assume uma interna dimensão crítica.

\begin{abstract}
Claro que esta transformação não substitui a crítica, porque o espaço de produção discursiva sobre as obras de arte se manteve, embora com alterações substanciais no entendimento do processo judicativo, que passou de um discurso ancorado em Kant, prescritivo e autocrático, para um discurso interpretativo sucessivamente informado pela psicanálise, pela antropologia, pela sociologia, pela teoria política, pelos estudos de gênero ou por aquilo a que dantes se chamava filosofia. E, dentro de cada um desses campos de saber, por inúmeros posicionamentos teóricos, frequentemente declarados, outras vezes meramente latentes (SARDO, 2016, pp. 81-82).
\end{abstract}

Também procurando estabelecer diferenças e especificidades entre crítica e curadoria, Terry Smith argumenta que o que caracteriza o pensamento da crítica de arte é o registro das maneiras pelas quais os significados das obras são entendidos no momento em que são vistas pela crítica, de modo a comparar essas impressões imediatas com referências diversas, trabalhos que o mesmo artista fez antes e outros realizados por diferentes artistas. Por outro lado, assinala que o pensamento curatorial, ainda que dedicado a tornar manifestos os mesmos elementos que preocupam os historiadores da arte e críticos, contém uma significativa diferença.

\begin{abstract}
Acima de tudo, a curadoria procura encorajar ou permitir a visibilidade pública de obras de artistas, seja montando uma seleção de obras existentes para exposição seja encomendando obras para exibição, para que possam ser vistas pela primeira vez por um público desinteressado ou vistas de outra maneira por tal audiência por causa das formas como são apresentadas. Neste modelo ideal, imaginário, a curadoria acompanha a resposta a uma nova obra de arte pelo círculo imediato do artista, e em muitos casos por aqueles interessados em disponibilizá-lo à venda ou desejá-lo comprá-lo, mas a curadoria precede a resposta crítica, a apreciação do público e a eventual avaliação do significado histórico-artístico (SMITH, 2012, p. 41-42, grifo meu).
\end{abstract}

Como já indiquei antes, também entendo que a curadoria resulta em algo a ser disponibilizado e exposto como objeto de apreciação, julgamento e escrutínio públicos. Ao argumentar que o pensamento curatorial não busca o julgamento das obras pelo simples fato da consciência de quão provisórias são suas proposições e definições, Terry Smith estabelece outra diferenciação no que toca à crítica e à história da arte, explicitando o que seria uma limitação das possibilidades do curador: 


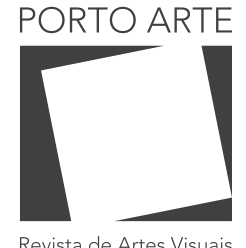

v. 25 n. 43 Jan/Jun 2020 e-ISSN: 2179-8001
Críticos e historiadores, em comparação, buscam declarações mais fortes e mais definitivas sobre a natureza e o significado da arte que eles encontram e estudam. Os curadores fazem todo o necessário para levar os trabalhos até o ponto em que podem se tornar sujeitos de um julgamento crítico e histórico. Eles exercem um repertório de habilidades e competências muito semelhante e são movidos por um conjunto de paixões e compromissos muito semelhantes, mas os curadores, nessa leitura, são avaliadores, não juízes. Nem são principalmente cronistas, como os historiadores da arte devem ser (mesmo do presente e especialmente do passado imediato) (SMITH, 2012, p. 44, grifo meu).

Pode-se concordar em parte ou não com essas afirmações, e também considerá-las um tanto esquemáticas. Seja como for, entendo ser importante perceber menos as especificidades do que os borramentos e as sobreposições entre as funções e os papéis do crítico e curador, assim como um impacta no outro. Ao reconhecer também a curadoria como um atividade fundada no entrelaçamento entre crítica e história da arte, Glória Ferreira (2010) chama atenção para o papel análogo de mediador entre as bases teóricas e históricas e as obras em exposição. Além da atividade propriamente crítica - de mediação entre o caráter singular das produções e seu sentido coletivo -, a curadoria seria habilitada a fornecer questionamentos acerca das narrativas historiográficas, em particular das visões hegemônicas e do sentido de evolução linear. Assim, ao propor novos parâmetros, a curadoria "tem contribuído largamente para a apreciação de trajetórias de artistas, de períodos e tendências bem como para novas visadas historiográficas" por meio de confrontos e leituras interpretativas que revelam "correspondências entre obras de diferentes períodos", levando a "desacreditar categorizações em estilos ou conceitos de evolução histórica" (FERREIRA, 2010, p. 138).

Quanto ao aspecto crítico que a curadoria pode encontrar, observo uma interessante argumentação em Beatrice Von Bismarck. No texto "Curatorial Criticality - On The Role of Freelance Curators in The Field of Contemporary Art", a historiadora da arte e pesquisadora alemã defende que o potencial crítico da constituição de significados simbólicos está no que seria o procedimento-chave da curadoria: o de criar conexões como estratégia específica de criticidade. As conexões a que se refere envolveriam as questões culturais, políticas, sociais e econômicas, no intuito de atingir uma postura crítica quanto aos projetos apresentados. Isso se relaciona aos procedimentos de escolher, vincular, apresentar e comunicar de maneira que reflita sobre essas relações, condições e mesmo os efeitos dos próprios atos.

Talvez mais do que qualquer outra profissão no campo da arte, a práxis curatorial é definida por sua produção de conexões. Os atos 


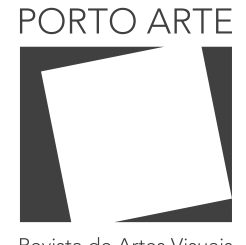

Revista de Artes Visuais de coletar ou montar, ordenar, apresentar e comunicar, as tarefas básicas da profissão curatorial, relacionam-se com artefatos de uma ampla variedade de fontes, entre as quais eles estabelecem conexões.

As possibilidades para tais conexões são múltiplas e, uma vez que os objetos foram removidos de seus contextos originais, também podem ser construídos de novo. Como objetos expostos, os materiais reunidos estão "em ação": isto é, obtêm significados mutáveis e dinâmicos no decorrer do processo de estarem relacionados uns com os outros. Idealmente, essas conexões resultam de características formais e estéticas ou de conteúdo, masestão relacionadas aos contextos culturais, políticos, sociais e econômicos correspondentes que anexam aos objetos expostos sua historicidade (BISMARCK, 2011, p. 19, grifo meu).

Interessante notar que esse postulado quanto a criar conexões, entendido como operação crítica, aparece também em Maria Lind. Em um conhecido e bastante referenciado texto, intitulado "The Curatorial", a curadora e pesquisadora sueca afirma que a curadoria é uma forma de pensar em termos de interconexões, no sentido de "ligar objetos, imagens, processos, pessoas, locais, histórias e discursos no espaço físico como um catalisador ativo, gerando reviravoltas, voltas e tensões" (2010, p. 63):

[...] a curadoria seria uma presença mais viral que consiste em processos de significação e relações entre objetos, pessoas, lugares, idéias e assim por diante. Uma presença que se esforça para criar atrito e empurrar novas idéias. [...] Em vez de representar, "a curadoria" envolve a apresentação - ela performa algo no aqui e agora, em vez de simplesmente mapeá-lo de lá e então (LIND, 2010, pp. 64-65, grifo meu).

Sob essa perspectiva, o resultado e a potencialidade crítica de uma curadoria passam a ser considerados como algo que emerge da multiplicidade dessas conexões propostas e incitadas. E também em como são orquestradas para desafiar o status quo desde as próprias obras e trabalhos artísticos colocados em causa no centro do projeto curatorial.

\section{4 - Entre o dizível e o visível}

No encaminhamento da discussão conforme procurei desenvolver até aqui, procurei evidenciar o caráter de inscrição pública e social que a crítica, a exposição e a curadoria assumem. Nesse sentido, para prosseguir no aprofundamento da reflexão, 


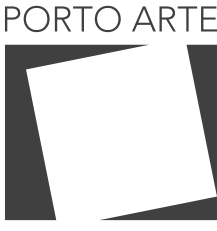

Revista de Artes Visuais

$\vee 25 n .43$

Jan/Jun 2020 e-ISSN: 2179-8001

lanço a seguinte questão: considerando o decréscimo da presença da crítica de arte na imprensa e os crescentes deslocamentos do discurso crítico para a esfera da apresentação, mediação e recepção do trabalho de arte no âmbito institucional; em que medida a curadoria em artes visuais pode se configurar enquanto extensão e desdobramento da crítica de arte?

Importante reiterar que a questão se refere em grande parte a alterações e substituições de papéis, ou mesmo a borramentos de fronteiras e distinções; mas também à constituição de uma nova posição de destaque nos processos de mediação da arte. Nesse sentido, no âmbito das exposições constata-se que é inegável que a curadoria tenha passado a exercer uma pronunciada instância de mediação em torno da produção artística e da história da arte.

E isso conduz nossa discussão aos discursos e às narrativas dos textos curatoriais, que não somente desenvolvem a defesa do argumento curatorial, como também assumem caráter poético e tom ensaístico, mesclando historiografia e crítica de arte, muitos vezes enfatizando um caráter interdisciplinar. Esses discursos críticos, se assim podemos chamá-los, difundem-se em livros, publicações e catálogos produzidos a propósito de mostras temporárias e com circulação no âmbito do circuito artístico.

Pelo caráter de inscrição e manifestação pública desses textos, autores como Anna Maria Guasch (2000, p. 5) chegam a considerá-los como os novos manifestos artísticos, que se seguiriam aos manifestos das vanguardas históricas e das neovanguardas, mas não sem envolver uma renovada complexidade que incide sobre uma trama de interesses e valoração. Ahu Antmen (2005, p. 69) tem entendimento semelhante, observando que "é interessante notar que com a ascensão do curador deparamos com um tempo em que duas formas de escrever sobre arte têm diminuído lentamente". Ela se refere primeiramente ao manifesto, "geralmente escrito por artistas e considerado a marca da obra de arte vanguardista", e afirma: "o curador tem que escrever o manifesto. O curador também começa a promulgar o manifesto". A segunda forma de escrita seria exatamente a crítica de arte.

\footnotetext{
Nós todos sabemos que a crítica de arte começou no século XVIII como um gênero literário com Denis Diderot. Como Thomas Crow explica em sua introdução à obra de Diderot, a demanda por tais comentários era um produto da similar institucionalização das exposições públicas. [...] 0 papel do crítico, então, como agora - colocando de modo simples - era dar seu parecer sobre a exposição, para identificar e analisar obras de interesse e esclarecer o público (ANTMEN 2006, p. 69).
}

Tanto nas considerações de Ahu Antmen como nas de Anna Maria Guasch fica evidenciada uma compreensão de que o curador passa a exercer um papel como agente discursivo por meio das exposições e de seus textos - ou manifestos, para usar a expressão sugeridas pelas autoras. Em ambos os casos, porém, assumindo um ale- 


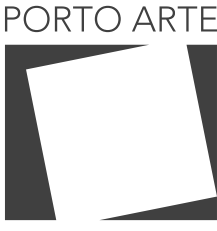

Revista de Artes Visuais

$\vee 25 n .43$

Jan/Jun 2020 e-ISSN: 2179-8001

gado protagonismo na função de mediação entre arte e público que antes era mais reservada ao estrito papel do crítico.

Neste ponto, considero oportuno lançar outras perguntas: configurar-se-iam esses textos relacionados a exposições e curadorias também como crítica de arte? Ao menos um tipo de crítica de arte? Ou seria mais adequado vê-los como uma modalidade de discurso crítico distinta da crítica de arte? Por outro lado, se tivermos em conta a propalada crise da crítica diante do verificado decréscimo de sua presença na imprensa escrita, seriam os textos curatoriais o seu substituto na esfera de medição entre arte e público? Nessa senda, ocupariam os curadores a posição de poder na legitimação dos valores artísticos antes exercida em grande parte pelos críticos?

o que me leva a formular tais questões em torno do estatuto crítico dos textos de curadores e de outros autores nas publicações relativas às exposições é o fato de serem escritos por críticos de arte, historiadores da arte, teóricos e especialistas em arte ou outras disciplinas. Na posição de curadores de exposição ou de autores convidados a escrever, desenvolvem discursos críticos por meio de textos que também funcionam como argumentação conceitual a fornecer as bases estruturantes das respectivas curadorias ou, ao menos, uma espécie de extensão e apêndice sobre os objetos e as questões colocadas em causa nas mostras.

E disso surgem outras questões. Se esses textos são de parte do curador, normalmente trazem como argumentação uma sustentação do projeto, expondo a reflexão sobre o conceito e o mote crítico. Ou seja, apresentam o desenvolvimento da forma autoral do tema e da problemática estruturante que dá perspectiva e razão de ser à exposição. São, assim, escritos que criam uma aproximação ao objeto da exposição e ao campo de indagação a partir dos vetores que orientam e fundamentam os seus critérios. Por esse caráter de apresentação, defesa e afirmação, ganham também a designação de declaração curatorial, que em inglês corresponde a um termo com uso bastante corrente no panorama de exposições - statement curatorial.

Em outra direção, se os textos são de autores convidados que não estejam envolvidos diretamente com a curadoria da exposição, comumente enveredam por um trajeto analítico e reflexivo sobre a mesma, parecendo, na maior parte das vezes, evitar a polêmica e a crítica negativa. Afinal, são textos encomendados pelas instituições para cumprirem certa função, o que os torna de antemão comprometidos com uma abordagem pré-determinada e uma lógica previamente estabelecida. Por serem feitos "sob medida", com define Guy Amado (2006, p. 241), constituem o que aqui designarei por "comissionamento de textos" no âmbito do circuito, tomando emprestada a expressão "commissioned writing" desenvolvida na introdução do livro "Spaces for Art Criticism - Shifts in Contemporary Art Discourses" (GIELEN, LIJSTER, MILEVSKA, SONDEREGGER, 2015, p. 13). Assim, deve-se reconhecer que a tendência desses textos é a de se manifestar em tom laudatório, como observa Boris Groys (2015, p. 147), em razão de estarem comprometidos com a instituição pagante e com aqueles que exibem a obra do(s) $\operatorname{artista(s).~}$

Se assim for, ainda que gerem conhecimento e reflexão sobre os objetos ou as 


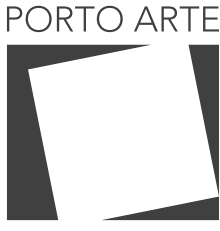

Revista de Artes Visuais

$\vee 25 n .43$

Jan/Jun 2020 e-ISSN: 2179-8001

questões colocadas pelas curadorias e pelas exposições, os textos escritos a propósito de exposições apresentam-se "em conformidade" à finalidade institucional, retomando a expressão de Ronaldo Brito antes convocada. Tal problemática leva a se refletir quanto às diferenças da crítica de arte e dos discursos críticos das curadorias. Afinal, a crítica que se dirige a uma exposição, mesmo que proporcionando discussão especializada sobre o mesmo objeto que o do curador, carrega em si a potencialidade de uma abordagem independente, exercitando, assim, um posicionamento avaliativo que se ofereça como questionamento ou, ao menos, acréscimo. Nesse sentido, convirjo com a observação do pesquisador português Bruno Marques.

[...] espera-se que a crítica "questione", no sentido em que deve fazer o escrutínio da pertinência e validade tanto no que concerne à prática artística como ao trabalho de curadoria, isto é, também apreciando a forma como é feita a sua mediação. Contribuindo para ampliar o debate ou fórum em torno da criação e da mediação, estas prerrogativas proporcionam que a crítica de arte funcione como um contraponto do que vem sendo produzido e apresentado (MARQUES, 2013, pp. 243-244).

É algo que não pode ser esperado de um texto curatorial por não corresponder à sua lógica. A meu ver, a distinção mais marcada entre o texto do curador e o texto do crítico de arte se assenta no fato de o curador abordar o que for favorável a seu projeto, enquanto o crítico de arte possuiu liberdade para contestar ou apreciar uma dada exposição, fazendo disso tema de especulação, debate ou mesmo polêmica.

Diante de tal discussão, interessa assinalar que, seja no caso do crítico seja nos casos daqueles autores relacionados à exposição como o curador e os convidados a escrever textos, os seus discursos tendem igualmente a se localizar e movimentar na esfera da apresentação, mediação e recepção do trabalho de arte no âmbito institucional. Portanto, como algo que envolve tanto os enunciados quanto os seus sujeitos de enunciação e os contextos nos quais eles são criados e circulam. Ao pensar sobre essas questões, não estou considerando que os textos curatoriais somente conteúdos escritos. Refiro-me em específico à capacidade de pensamento espacial por parte do curador, no sentido de propor enunciados, narrativas e discursos visuais e não textuais.

Em um texto já mencionado, "Dividir e coser: uma opinião sobre a relação entre crítica e curadoria", Delfim Sardo traz diversos elementos para se pensar nos afastamentos e aproximações entre crítica, exposição e curadoria. Argumenta que crítica e curadoria são, afinal, atividades distintas que empregam diferentes processos, mas para igualmente produzirem mediação artística em situação de disponibilização pública. 


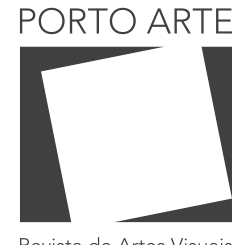

v. $25 n .43$ Jan/Jun 2020 e-ISSN: 2179-8001 tica, social, política, econômica e epistemológica da produção artística. As grandes diferenças entre estas duas tipologias de atividade em torno da arte situam-se nos processos utilizados: a crítica é um subgênero literário e utiliza sobretudo o discurso, normalmente escrito, mas por vezes também outros suportes; a curadoria é uma prática comparativa que se materializa em suportes normalmente espaciais, vulgo exposições. Podem ter lugar em galerias, no espaço público ou em estruturas temporalmente definidas, mas requerem sempre um dispositivo espacial (SARDO, 2016, p. 79, grifo meu).

Algumas especificidades pontuadas por Delfim Sardo colaboram no prosseguimento da discussão. Entendo que a crítica de arte, por seu caráter textual, configura-se como um discurso estabelecido conforme uma ordem, a da orientação da leitura. Isso não significa que ofereça uma leitura única, em especial se tivermos em conta as noções bastante referenciadas de autor e leitor em teorizações como as de Walter Benjamin, Michel Foucault, Roland Barthes e Giorgio Agamben, além do conceito de obra aberta nos termos de Umberto Eco. Mas, ainda que tais teorizações ofereçam aportes para se formular um campo de problemas em torno das funções e dos papéis do autor e do leitor, entendo que a crítica de arte é ligada ao regime da palavra, ou seja, da escrita e do dizível.

Já a curadoria, pela dimensão espacial e vivencial da exposição, está a meu ver ligada à experiência do visual e do fenomenológico, situando-se portanto também no regime do visível e do experencial. Ao considerar as diferenças entre os regimes do ver e do dizer, não se trata de estabelecer hierarquias entre essas diferentes competências dos regimes perceptivos nem de associar o dizível ou o visível como mais próximos ou mais distantes do saber e da experiência. Nesse sentido, Ana Maria Albani de Carvalho assinala um aspecto que julgo pertinente, ao refletir sobre o lugar do texto em uma exposição curatorial e o estatuto que é próprio à dinâmica de uma visita a exposições.

Trata-se de ter em conta que a curadoria não se manifesta efetivamente no texto (crítico) publicado no catálogo e sim na disposição das obras selecionadas no contexto do espaço de exposição. Ao visitar uma exposição, o espectador pode realizar, a sua maneira as mesmas operações que estão na base do exercício da curadoria: ele observa, seleciona, compara, interpreta. Operações que não precisam (e raramente o são) realizadas na ordem (isto é, no circuito de visitação estabelecido/concebido) pelo curador ou pela expografia (CARVALHO, 2014, p. 269, grifo meu).

Se assim for, o texto curatorial, ainda que em muitos casos seja fundante ou nuclear do mote temático e conceitual de uma exposição, tende a ocupar um lugar não central na experiência do espectador, não determinando efetivamente a interpretação 


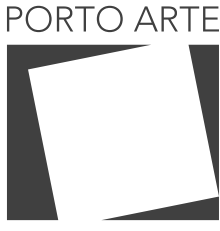

Revista de Artes Visuais

v. 25 ก. 43

Jan/Jun 2020 e-ISSN: 2179-8001

do observador diante da experiência no espaço expositivo, naquilo que vivencia em termos fenomenológicos, a partir do recorte espaço-temporal.

Também discutindo os textos curatoriais e os catálogos que os apresentam, Terry Smith argumenta que, do ponto de vista da experiência de um visitante a uma exposição, tendem a exercer papel secundário. 0 que demonstraria não somente a prevalência em uma exposição dos aspectos presencial, vivencial e fenomenológico há pouco mencionados, mas também a não garantia de que o argumento curatorial empreste algum tipo de filtro que efetivamente influencie ou mesmo oriente a recepção.

Dentro do espaço da exposição em si, a interpretação do curador permanece não declarada, implícita. Em sua forma explícita, geralmente torna-se disponível para o espectador mais tarde - no catálogo, por exemplo - como um complemento ao entendimento de que ele ou ela já chegou enquanto apreciava a exposição (SMITH, 2012, p. 45 , grifo meu).

Todavia, ainda com relação aos textos, considero que seja importante ressaltar que a sua acomodação em catálogos constitui, do ponto de vista da história e da crítica de arte, uma peça discursiva de registro e documentação que participa destas disciplinas. Ana Maria Albani de Carvalho ressalta o caráter interpretativo que oferecem:

[...] o catálogo se constitui, a rigor, como uma outra linguagem e modalidade de interpretação da exposição, na medida em que apresentará o texto do curador (geralmente com a argumentação sobre suas intenções norteadoras e os critérios adotados para a seleção de obras e artistas) acrescido das imagens das obras e/ou da exposição montada. As opções adotadas na edição de textos, imagens e no design gráfico do catálogo não devem ser reduzidas ao estatuto de mero registro da exposição. Descrever envolve selecionar e definir e estes procedimentos, como sabemos, constituem um trabalho de interpretação (CARVALHO, 2012, p. 54).

Acrescentaria a essa visão as especificidades de países como o Brasil, onde presenciamos uma história (e historiografia) da arte fraturada, com poucos livros que contemplem um intervalo de tempo mais largo e com um recorte mais abrangente de abordagem da arte brasileira. Em certa medida, os catálogos correspondem a essa historiografia da arte fragmentada, que se constitui em grande parte por ensaios, relatos, comunicações e artigos que se dispersam em um mapeamento de antemão multifacetado e lacunar. Daí, portanto, um dado de importância assumida pelas publicações produzidas a propósito de exposições e curadorias no âmbito institucional. 


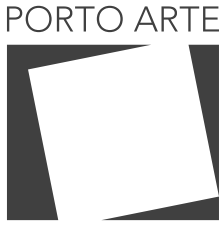

Revista de Artes Visuais

$\vee 25 n .43$

Jan/Jun 2020 e-ISSN: 2179-8001

Porém, deve-se considerar a realidade que recai sobre essas publicações, limitando-as em sua densidade e extensão de documento, pois na maioria das vezes os catálogos são preparados às vésperas das exposições para estarem prontos pontualmente na abertura. Como discute Jennifer Allen no texto "Futures Trading - How Do You Write a Catalogue Essay dor a Show That Hasn't Yet Opened?", esse expediente geralmente exclui a possibilidade de incluir tomadas da montagem e da expografia, assim como a ocupação de trabalhos de caráter instalativo. Daí o questionamento da autora sobre o tom de futurologia que assumem os catálogos realizados antes da existência da exposição. Afinal, ela pergunta: "o que distingue uma exposição de uma simples lista de obras se não a montagem do curador e o espaço da exposição?" (ALLEN, 2009).

Retomando a discussão anterior, a questão, portanto, está em reconhecer que a curadoria opera em ambos os regimes, o dizível e o visível. Como uma exposição jamais escapa de um pensamento teórico que a sustente, o curador deve desempenhar, pelo menos, duas atividades simultâneas: a de organizar a exposição e a de fazer a sua crítica. Mas ainda que elabore a crítica que sustenta a sua exposição, o curador estará fazendo uma crítica que já parte de um dado estabelecido e de um determinado recorte. Pois, ao contrário do crítico stricto sensu, o curador elabora seu pensamento teórico-conceitual em uma prática de contato direto com as obras ou práticas e processos artísticos que são objeto da exposição, materializando, de dentro de um conjunto delimitado e de um horizonte finito, um discurso que é também visual por se configurar na montagem. Ou seja, com a expografia o curador formula igualmente um discurso, só que espacial. Isso reitera a questão há pouco colocada, de que, por mais que o enunciado escrito fundamente o discurso expositivo, a orientação em que se dá a legibilidade e compreensão de ambos não pode ser garantida nem conduzida totalmente pelo curador, escapando a seu poder e controle. Nesse sentido, não há uma determinação e um desígnio garantidos totalmente a priori pelo curador.

Esse ponto permite ir ao encontro de outro aspecto já antes assinalado, sobre a experiência de um observador em uma exposição se dar de acordo com suas escolhas e o modo com que articula o que vê a suas experiências anteriores - nesse sentido, não muito diferente do crítico. É algo que se aproxima da teoria com que Jacques Rancière (2009, pp. 20-21) reflete sobre o poder comum aos espectadores, enquanto "poder que cada um tem de traduzir à sua maneira o que percebe, de relacionar isso com sua aventura intelectual singular que o torna semelhante a qualquer outro".

Assim, a potencialidade crítica encontraria meios de se efetivar não na ideia de transmissão de um saber, mas justamente nesse encontro horizontal e aberto entre iguais, associado "ao poder comum aos espectadores", na possibilidade emancipatória de cada um formular por si e por seus meios a sua própria experiência, como um jogo imprevisível de associações e dissociações.

Esse poder comum da igualdade das inteligências liga indivíduos, faz com que eles intercambiem suas aventuras intelectuais, à medida que os mantêm separados um dos outros, igualmente 


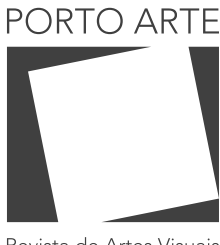

v. 25 ก. 43 Jan/Jun 2020 e-ISSN: 2179-8001 capazes de utilizar o poder de todos para traçar seu caminho próprio (RANCIÈRE, 2009, pp. 20-21).

É justamente esse caráter do comum que nos devolve às relações entre crítica, exposição e curadoria. Ou sobre a potencialidade crítica da curadoria, como há pouco sugeri. Afinal, um discurso curatorial, mesmo implicado por falar a partir de dentro, pode encontrar condições de impulsionar revisões de significações e questionamentos de pressupostos. Para Lisbeth Rebollo Gonçalves, essa operação é uma tarefa crítica, pois indica que o papel do curador corresponde ao que o crítico faz ao interpretar a arte de diferentes momentos. Essa aproximação se reforça, conforme a autora, pois tanto no discurso curatorial quanto na crítica de arte há "uma tomada de partido", uma vez que "não há possibilidade de que uma exposição seja um discurso neutro" (GONÇALVES, 2008, pp. 45-56).

Esse é um aspecto também abordado por Lisette Lagnado no texto "As tarefas do curador", no qual afirma que toda exposição - e, eu acrescentaria, toda curadoria - "depende de uma intenção crítica, de um projeto" (2008, p. 10). Lisette Lagnado argumenta que a curadoria, embora sendo um espaço crítico, se distinguiria da crítica por "determinar ênfases seletivas, sem menosprezar o fato de que exclusões fazem parte da construção de um paradigma". Destaco em seu argumento a importância dada ao enunciado espacial no trabalho de curadoria, algo que se dá juntamente e além do enunciado textual.

A afirmação de que nem todo crítico é curador procede, uma vez que a função máxima do crítico é escrever, e ele pode passar a vida sem a obrigação de responder por uma exposição ou um acervo de obras. Inversamente, a sentença nem todo curador é crítico é suspeita, porque toda exposição exige um teor propositivo ou de contestação. Ora, sem intenção ao lançar os dados, a exposição desliza para o regime do aleatório. Sendo assim, autoritária é a exposição que não tem objetivo nem justificativa, pois a esses parâmetros ainda é possível retrucar. Caso a exposição não tenha uma hipótese - ou uma utopia -, ela se encerra em si mesma (LAGNADO, 2008, p. 10, grifo meu).

É nesse sentido que Lisette Lagnado argumenta que a tarefa do curador não é dissociada de uma atitude crítica, uma vez que para se fazer crítica "a pesquisa se impõe como primeira condição de um processo de aquisição e distribuição de saberes e verdades" (p. 14). É uma opinião semelhante à de Paulo Herkenhoff, segundo quem a curadoria é "um processo de reflexão, não um processo de coleta de obras" (2011, p. 68), é "submeter uma obra de arte a uma hipótese hermenêutica" (2008, p. 23), sendo "produção de conhecimento a partir da intimidade com as obras" (2008, p. 23).

Assim, na apresentação de determinado conjunto de obras em uma exposição, estando elas agrupadas e relacionadas em torno de um título, tema ou conceito, en- 


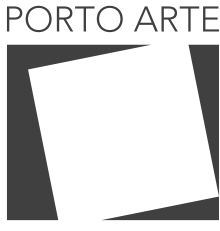

Revista de Artes Visuais $\vee 25 n .43$ Jan/Jun 2020 e-ISSN: 2179-8001

tendo que há sempre uma tomada de posição que não é neutra nem isenta. Nesse sentido, a curadoria geralmente transpareceria publicamente em um tripé: a disposição das obras na montagem da mostra, os textos apresentados no espaço expositivo e a publicação do catálogo com imagens e textos. Para Diana Beatriz Wechsler, tais textos e imagens encontram sentido crítico desde que se ofereçam como um posicionamento que se abra à discussão. Nesse sentido, discursos e gestos da atividade curatorial encontrariam também implicação política:

Trata-se de pensar a produção curatorial e a produção de textos críticos como ações políticas (entendidas como estratégias de posicionamento dentro do espaço da produção de saberes), dado que são gestos responsáveis pela delimitação de um corpus e um olhar preciso sobre certos aspectos do mundo contemporâneo; constróem representações socioculturais de índole distinta, intervindo na formação de diversas noções identitárias de gênero, nação, região, classe etc. (segundo os casos), que vão se instalando no imaginário de nossas sociedades (WECHSLER, 2010, p. 70).

A meu ver, a possibilidade de um discurso curatorial ser também um discurso crítico está no sentido de envolver escolhas segundo critérios, opções, escolhas e exclusões, constituindo-se enquanto objeto de discussão, análise, reflexão e mesmo de escrutínio público. De certo modo, isso retoma a ideia de conexões conforme visto antes a partir das discussões de Maria Lind e Beatrice von Bismarck. Em uma perspectiva que identifico próxima, quanto ao expediente das conexões que se efetivam na montagem de uma exposição, Ana Maria Albani de Carvalho destaca o que seria a potencialidade crítica da curadoria:

Embora tanto uma prática quanto a outra possa ser definida como discurso, entendemos que configurem dois regimes distintos, sendo a crítica ligada ao da palavra e ao legível, e a curadoria, por sua vez, comportando uma dimensão propriamente fenomenológica, ligada ao regime da experiência sensível, estética, ao campo do visível. Isto porque entendo que a curadoria se manifesta especificamente na situação da montagem, através das relações estabelecidas entre as obras, um determinado lugar e uma determinada experiência, no caso, a do espectador que visita (e anima) a exposição. A atividade crítica - no sentido de escolha segundo critérios, passíveis de argumentação e debate - é entendida como fundadora da atividade curatorial. A potencialidade crítica da curadoria decorre desta relação, embora possa ou não realizar-se efetivamente (CARVALHO, 2014, p. 264, grifo meu). 


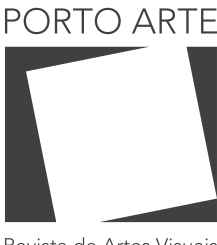

v. $25 n .43$ Jan/Jun 2020 e-ISSN: 2179-8001

O argumento não deixa de estabelecer também uma aproximação com Delfim Sardo (2016, p. 83), para quem a exposição e a curadoria assumem dimensão crítica por engendrarem políticas de apresentação em um "processo de permanente reformulação da recepção", enquanto a prática crítica "continua a reverberar sentidos divergentes e a não se poder converter numa negociação em torno das circunstâncias de recepção, porque ainda é válida a possibilidade de renovar protocolos, mesmo que temporários e históricos, para o exercício de processos judicativos".

Como modo de finalizar, considero importante assinalar e mesmo reiterar que a discussão e a reflexão conforme aqui se procurou desenvolver e colocar em causa se referem a questões que são de ordem constitutiva de um conjunto de transformações ainda não cessadas e em curso, sinalizando por isto a necessidade do dever crítico, em sua exigência de permanente questionamento e redefinição dos diferentes âmbitos da crítica, da curadoria e da exposição, não sem desconsiderar como repercutem nas noções de arte, artista, público, instituição e seus agentes. Acredito que ter essa compreensão em conta é fundamental para se analisar e compreender as condições em que a atividade curatorial vem se desenvolvendo enquanto espaço de crítica - e, portanto, em que medida seria possível pensá-la e tomá-la como desdobramento da atividade crítica e também potencial instância crítica atuando desde o endereçamento e enquadramento institucional.

\section{REFERÊNCIAS}

ALAMBERT, Francisco. "Redefinição de papéis". Revista do Sesc, n 218, ago. 2014, $\mathrm{s} / \mathrm{n}^{\circ}$. Online. Disponível em: <https://www.sescsp.org.br/online/artigo/7804 CURADORIA+VERSUS+CRITICA+DE+ARTE>. Acesso em: 19 mai. 2020.

ALLEN, Jennifer. "Futures trading - How do you write a catalogue essay for a show that hasn't yet opened?". Frieze Magazine, London, n. 126, out. 2009, s/nº. Disponível em: <https://frieze.com/article/futures-trading?language=de>. Acesso em: 29 jul. 2018.

AMADO, Guy. "Notas sobre a jovem crítica de arte". In: FERREIRA, Glória (org.). Crítica de arte no Brasil: temáticas contemporâneas. Rio de Janeiro: Funarte, 2006, pp. 243-245.

ANTMEN, Ahu. "The Critic's Role in The Age of The Curator". In: Critical Evaluation Reloaded - 40th AICA Congress, Association of Art Critics (AICA), Paris, 15-20 October 2006, pp. 66-71.

BAUMAN, Zygmunt. Legisladores e intérpretes. Rio de Janeiro: Zahar, 2010.

BISMARCK, Beatrice Von. "Curatorial Criticality - On The Role of Freelance Curators in The Field of Contemporary Art". In: On Curating - Curating Critique, n. 9, Zurique, set. 2011, pp. 19-23.

BRITO, Ronaldo. "Questões de crítica e curadoria de arte". Encontros com a Arte Contemporânea - $1^{\text {a }}$ Edição. Vila Velha (ES): Museu Vale, 25-27 out. 2017. Vídeo 


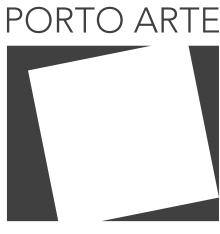

Revista de Artes Visuais

v.25 n 43 Jan/Jun 2020 -ISSN:2179-8001

de palestra. Disponível em: <https://www.youtube.com/watch?v=YESGEpEi3-o\&feature=youtu.be $>$. Acesso em: 7 maio 2020.

CARVALHO, Ana Maria Albani de. "A exposição como dispositivo na arte contemporânea: conexões entre o técnico e o simbólico". Museologia \& Interdisciplinaridade Revista do Programa de Pós-Graduação em Ciência da Informação, Universidade de Brasília, vol.1, n. 2, jul/dez de 2012, pp. 47-58.

CARVALHO, Ana Maria Albani de. "Curadoria e potencialidade crítica na arte pós-autônoma". Anais do XXXIII Colóquio CBHA - Arte e suas instituições, set. 2013. Campinas: Comitê Brasileiro de História da Arte - CBHA, 2014 [2013], pp. 257-272.

CARVALHO, Ana Maria Albani de. Instalação como problemática artística contemporânea: os modos de espacialização e a especificidade do sítio. 2005. 356f. Tese (Doutorado em Artes Visuais) - Programa de Pós-Graduação em Artes Visuais, Instituto de Artes, Universidade Federal do Rio Grande do Sul (UFRGS), Porto Alegre. Disponível em: <http://www.lume.ufrgs.br>.

CESAR, Marisa Flórido. "Curadoria: deslocamentos, impasses, possibilidades". Poiésis Revista do Programa de Pós-Graduação em Estudos Contemporâneos das Artes, Universidade Federal Fluminense, n. 26, dez. 2015, pp. 51-64.

DALCOL, Francisco. A curadoria de exposição enquanto espaço de crítica: a constituição de um campo de prática e pensamento em curadoria no Brasil (anos 19601980). 2018. 329f. Tese (Doutorado em Artes Visuais) - Programa de Pós-Graduação em Artes Visuais, Instituto de Artes, Universidade Federal do Rio Grande do Sul (UFRGS), Porto Alegre. Disponível em: <http://www.lume.ufrgs.br>.

FARIAS, Agnaldo. "Problemas da crítica e da curadoria no panorama recente da arte brasileira". In: COUTO, Maria de Fátima Morethy; FUREGATI, Sylvia Helena (orgs.). Espaços da arte contemporânea. São Paulo: Alameda, 2013, pp. 171-179.

FERREIRA, Glória. "Crítica e presentação". In: FERREIRA, Glória; PESSOA, Fernando (orgs.). Criação e crítica. Seminários Internacionais Museu Vale, 11-15 mar. 2009, Vila Velha (ES). Rio de Janeiro: Suzy Muniz Produções, 2009, pp. 188-199.

FERREIRA, Glória. "Escolhas e experiências". In: RAMOS, Alexandre Dias (org.). Sobre o ofício do curador. Porto Alegre: Zouk, 2010, pp. 137-148.

GIELEN, Pascal; LIJSTER, Thijs; MILEVSKA, Suzana; SONDEREGGER; Ruth. "Introduction: a Topology of Criticism". In: LIJSTER, Thijs; MILEVSKA, Suzana; GIELEN, Pascal; SONDEREGGER; Ruth (eds.). Spaces for Art Criticism - Shifts in Contemporary Art Discourses. Amsterdam: Valiz, Antennae Series, 2015, pp. 11-20.

GONÇALVES, Lisbeth Rebollo. "Arte contemporânea e crítica de arte". In: GONÇALVES, Lisbeth Rebollo; FABRIS, Annateresa (orgs.). Os lugares da crítica de arte. São Paulo: Imprensa Oficial do Estado, 2005, pp. 35-46.

GONÇALVES, Lisbeth Rebollo. Entre cenografias: o museu e a exposição de arte no século XX. São Paulo: Edusp, 2004.

GONÇALVES, Lisbeth Rebollo. "Exposição e crítica - um enfoque em duas direções". In: BERTOLI, Mariza; STIGGER, Verônica (orgs). Arte, crítica e mundialização. São Paulo: ABCA - Imprensa Oficial do Estado, 2008, pp. 45-56.

GROYS, Boris. "Reflexões críticas". In: Arte poder. Belo Horizonte: UFMG, 2015, pp. 141- 


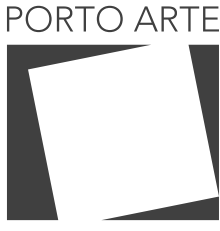

Revista de Artes Visuais

$\vee 25 n .43$ Jan/Jun 2020 e-ISSN: 2179-8001

149.

GUASCH, Anna Maria. "Prólogo". In: GUASCH, Anna Maria (ed.). Los manifestos del arte posmoderno: textos de exposiciones 1980-1995. Madri: Akal, 2000, pp. 5-8.

HERKENHOFF, Paulo. "Bienal 1998: princípios e processos". Marcelina - Revista do Mestrado em Artes Visuais da Faculdade Santa Marcelina, São Paulo, ano 1, v.1, $1^{\circ}$ sem. 2008, pp. 20-36.

HERKENHOFF, Paulo. "Rodadas - Qual o perfil da curadoria brasileira e o que ela precisa para profissionalizar-se". Mesa de debate. In: TEJO, Cristiana (coord.). Panorama do pensamento emergente. Porto Alegre: Zouk, 2011, pp. 64-69.

HUGHES, Henry Meyric. "A história e a importância da Bienal como instrumento de globalização". In: BERTOLI, Mariza; STIGGER, Verônica (orgs.). Arte, crítica e mundialização. São Paulo: ABCA - Imprensa Oficial do Estado, 2008, pp. 19-43.

JUSTINO, Maria José. "Criticar... é entrar na crise: uma perspectiva histórica da crítica de arte". In: GONÇALVES, Lisbeth Rebollo; FABRIS, Annateresa (orgs.). Os lugares da crítica de arte. São Paulo: Imprensa Oficial do Estado, 2005, pp. 13-54.

LAGNADO, Lisette. "As tarefas do curador". Marcelina - Revista do Mestrado em Artes Visuais da Faculdade Santa Marcelina, São Paulo, ano 1, v.1, $1^{\circ}$ sem. 2008, pp. 8-19.

LEENHARDT, Jacques. "Crítica de arte e cultura no mundo contemporâneo". In: MARTINS, Maria Helena (org.). Rumos da crítica. São Paulo: Editora Senac/ltaú Cultural, 2000, pp. 19-28.

LIND, Maria. "The Curatorial". In: Selected Maria Lind Writing (Brian Kuan Wood, ed.). Berlin: Sternberg Press, 2010, pp. 57-66.

MARQUES, Bruno. "Curadores críticos: o caso de Julião Sarmento". In: AFONSO, Lígia; PINHEIRO, Gabriela Vaz; SEIXAS, Luísa (orgs.). Laboratório de curadoria. Guimarães: Guimarães 2012 Capital Europeia da Cultura, 2013, pp. 234-250.

MORAIS, Frederico. "Do corpo à terra: um marco radical na arte brasileira" [2001]. In: FERREIRA, Glória (org.). Crítica de arte no Brasil: temáticas contemporâneas. Rio de Janeiro: Funarte, 2006, pp. 195-200.

OGUIBE, Olu. "O fardo da curadoria". Concinnitas, Revista do Instituto de Artes da UERJ. Rio de Janeiro, vol. 5, n 6, jul. 2004, pp. 6-17.

O'NEILL, Paul. The Culture of Curating and The Curating of Culture(s). Cambridge and London: The MIT Press, 2012.

OSORIO, Luiz Camillo. "Virada curatorial: o pôr-em-obra da exposição como poética relacional". Poiésis - Revista do Programa de Pós-Graduação em Estudos Contemporâneos das Artes, Universidade Federal Fluminense, n. 26, dez. 2015, pp. 65-80.

RANCIĖRE, Jacques. A partilha do sensível. São Paulo: EXO experimental org., Editora 34, 2009.

REINALDIM, Ivair. "Tópicos sobre curadoria". Poiésis - Revista do Programa de Pós-Graduação em Estudos Contemporâneos das Artes, Universidade Federal Fluminense, n. 26, dez. 2015, pp. 15-28.

SARDO, Delfim. "Dividir e coser: uma opinião sobre a relação entre crítica e curado- 


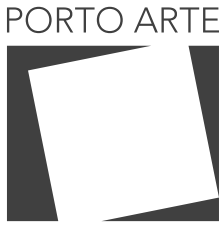

Revista de Artes Visuais

v. 25 n. 43 ria". In: CRESPO, Nuno (org.). Arte.crítica.política. Lisboa: Tinta da China edições, 2016, pp. 77-83.

SMITH, Terry. Thinking Contemporary Curating. New York: Independent Curators International, 2012.

WECHSLER, Diana Beatriz. "Relatos curatoriais, relatos políticos". In: JAREMTCHUK, Dária; RUFINONI, Priscila (orgs.). Arte e política - situações. São Paulo: Alameda, 2010, pp. 69-86.

ZIELINSKY, Mônica. "A arte e sua mediação na cultura contemporânea". In: FERREIRA, Glória (org.). Crítica de arte no Brasil: temáticas contemporâneas. Rio de Janeiro: Funarte, 2006, pp. 221-226. 


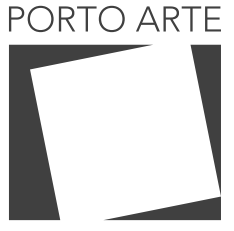

Revista de Artes Visuais

v. 25 n. 43

Jan/Jun 2020 e-ISSN: 2179-8001

Texto recebido em: 15/06/2020 Texto publicado em: $30 / 06 / 2020$

\section{Francisco Dalcol}

Pesquisador, crítico, historiador da arte, curador e editor. Atual diretor-curador do Museu de Arte do Rio Grande do Sul (MARGS) e professor-colaborador do curso de especialização (lato sensu) Práticas Curatoriais, do Instituto de Artes da Universidade Federal do Rio Grande do Sul (UFRGS). Doutor (PPGAV/UFRGS) e Mestre (UFSM/PPGART) em Artes Visuais - História, Teoria e Crítica, com estágio de doutoramento no exterior pela Universidade Nova de Lisboa (UNL). Sua pesquisa de doutorado trata das interseções entre crítica de arte, exposição e curadoria, tendo defendido em 2018 a tese intitulada "A curadoria de exposição enquanto espaço de crítica: a constituição de um campo de prática e pensamento em curadoria no Brasil (anos 1960-1980)". É membro da Associação Internacional de Críticos de Arte (AICA), da Associação Brasileira de Críticos de Arte (ABCA) e da Associação Brasileira de Pesquisadores em Artes Plásticas (ANPAP) - Comitê de Curadoria. 